\title{
Joshua Ezra Burns The Christian Schism in Jewish History and Jewish Memory
}

(Cambridge: Cambridge University Press, 2016), hardcover, ix +293 pp.

\author{
ANDERS RUNESSON \\ anders.runesson@teologi.uio.no \\ University of Oslo, 0315 Oslo, Norway
}

Few questions have engaged scholars involved in Jewish-Christian dialogue more than the problem of the so-called parting of the ways. When, where, and, most importantly, how and why did Jews and Christians go their separate ways? These types of questions cannot easily be reduced to a modern fixation on origins, assuming that historical reconstruction would automatically result in ready-made authoritative conclusions for consumption in the contemporary world. For more than a millennium and a half, Jews and Christians have made normative claims about one another, drawing on historical assertions about the earliest period of interaction, which were meant to cement boundaries, maintain difference, and solidify identity through distance.

Modern historical scholarship, when disentangled from the normative constraints of religious communities, has problematized many of these traditional claims that have sustained distinct boundaries and identities. New historical scenarios have emerged, which more fully take into account the available source material. This, in turn, has opened up new horizons for Jews and Christians today to understand one another for who they are, based on a more realistic assessment of the past. History is still an important tool in inter-religious conversations, although it is considered now from a more hermeneutically informed perspective.

It is in light of such developments that Professor Burns' book, based on his 2010 Yale University dissertation, may be approached, as he seeks to "document a misunderstood chapter of the Jewish experience in antiquity" (p. 17) with the aim of writing a history from the Jewish side of the schism with what became Christianity (p. 12). For Burns, there is more than history at stake here, as he writes "as a Jew committed to [his] religion and to the collective welfare of [his] people." It is his express hope that his historical work will provide a foundation for the theological dialogue between Jews and Christians, which he understands as a vital conciliatory effort of key importance to both religions (cf. p. 15). 
The Introduction begins with an interesting prelude discussing the infamous Paris trial of the Babylonian Talmud in 1240 (pp. 1-18). The prelude cleverly places Burn's own work - which is aimed at understanding history beyond the perspectival constraints of the rabbinic texts - in a historical context in which Jewish authorities have long recognized that the Talmudic perception of Jesus cannot be understood as historically accurate. As Burns prepares his readers, "we must dare to confront the inadequacies of what we think we know about the other even if at risk of revealing discomforting truths about ourselves" (p. 18). To make his task manageable, Burns delimits his study geographically to Roman Palestine and chronologically to the period between the first and the third centuries CE.

The chapters that follow describe a logical sequence of exemplary clarity. In order to ask a question at all, one needs to understand what the question itself assumes, and how it controls the investigation it triggers from within. Thus, in chapter 1 Burns critically reviews how the topic of the parting of ways has been treated historically, from F. C. Baur onwards ("The Parting of the Ways in Contemporary Perspective"; pp. 19-60). Highlighting the social embeddedness of academic discourse, Burns concludes this section by stating his intention to distinguish between the "facts of the past" and their selective representation in the rabbinic record (p. 54). All players must be set on a "common dialogical plane." For Burns, the groups designated minim by the rabbis, including those he calls "Jewish Christians," must be understood as "legitimate Jewish actors" if historical reconstruction is to be the goal (p. 60). Important for the rest of the book is the recognition, now a growing consensus, that the rabbis did not control the Jewish community at this time, and that their construction of and perspective on the minim was just that: their construction and their perspective.

For Burns the interaction between the early Palestinian rabbis and their contemporary Christian neighbors should be studied as an inner-Jewish affair: "The only Christianity of which the rabbis knew was the type practiced by Jews" (p. 55). To solidify this claim, in chapter 2, "Jewish Identity in Classical Antiquity: Critical Issues and Approaches to Definition," Burns deals with definitions of Jewishness (pp. 61-99). Here, Burns offers criteria which could be said to constitute a sine qua non for maintaining a Jewish identity. The core convictions, founded on Torah and expressed in practices understood to uphold Jewish ancestral customs, included "circumcision, Sabbath observance, kashrut, and, until 70 CE, patronage of the Temple cult" (p. 99). Within these parameters, Burns acknowledges the existence of considerable diversity based on local customs linked to shifting emphases on (intertwined) religious and ethnic aspects of Jewish identity.

In chapter 3 Burns turns to the question of how different types of Christianity related to (his reconstruction of) the above-mentioned "minimum requirements" of Jewish identity, enabling him to judge whether or not any or all of these cultural expressions should be understood as Jewish ("Early Christian Negotiations with Jewish Identity," pp. 100-58). He settles on identifying two main types of Christianity. The first is represented by Paul, or rather, by receptions of Paul. Aligning himself with the approach of the so-called New Perspective on Paul, re- 
ferring to scholars such as J. D. G. Dunn, Burns argues that the Pauline gospel, influencing mainly the Roman west, demonstrates a break with Jewish identity. The second type of Christianity was one that, while not in conflict with the Pauline gospel, took it for granted that it did not apply to Jesus followers who were Jews. Their views are represented in the Gospel of Matthew, the Didache, and the Pseudo-Clementine literature, or, rather, a part of the Recognitions dependent on a late second-century source $(1: 27-71 ;$ p. 150), all of which he locates in the Roman east (Palestine and western Syria). The authors and readers of these texts were all of Jewish descent, and they interpreted their identity as a form of Judaism.

It was this specific form of Jewish Christianity that the Tannaim encountered, the implications of which Burns discusses in chapter 4, "Reading Christianity as a Jewish Heresy in Early Rabbinic Texts" (pp. 159-208; cf. esp. pp. 172, 181, 20708). Importantly, Burns locates these Jewish believers in Jesus in both churches and synagogues, thereby opening up for analysis of the interrelationship between Jesus followers and rabbinic groups on the one hand, and Jewish and non-Jewish Jesus followers on the other. As Burns rightly notes, the story of these Jewish believers in Jesus represents "a lost chapter in the history of the Jewish people" (p. 159). Tannaitic literature provides "the earliest surviving Jewish witnesses to Christianity as testaments to a schism not yet resolved but certainly well underway" (p. 160). From an early rabbinic perspective, which did not know of the non-Jewish forms of Christianity predominantly existing in the Roman west, the first signs of the schism (late-first to early-third centuries) were subtle, since the rabbinic heresiological process took place within a (Galilean) worldview in which Christians were seen as (misguided) fellow Jews (cf. p. 163). This understanding also implies a clear demarcation between Jewish and non-Jewish Christ followers, an overall picture reinforced by patristic evidence.

Finally, in chapter 5, "Shifting Demographics and the Making of a Schism" (pp. 209-52), Burns traces developments of the emerging schism into the fifth century, when, he argues, the split between "Christian" and "Jew" was complete. One contributing factor to this perception of separate identities was the increasing influence of the Amoraim over Jewish society. They sought the authorization of the Patriarchs to appoint local judicial agents, leading to the implementation of rabbinic halakhah on a larger scale than had hitherto been possible (cf. pp. 214 ff.). The overall trajectory of increased rabbinic influence in Jewish society meant, over time, the marginalization of Jewish followers of Jesus in Jewish communities. This happened at the same time as non-Jewish forms of Christianity came to dominate the religious landscape also of the Roman east, including Palestine, leaving the Jewish believers in Jesus very little conceptual-and institutional-space (cf. pp. 222, 239). As a result, these remaining Jewish believers in Jesus, Burns suggests, would likely have given up on their ancestral practices and assimilated into (gentile) Christian communities. And with that the schism would become complete. 
The book ends with an epilogue (pp. 253-54), a bibliography (pp. 255-88), and an all-too-brief index (pp. 289-93).

There is no question that this study is an important contribution to scholarship, even though some aspects of the book are, in this reviewer's opinion, in need of further work (see below). In addition to several of Burns' astute detailed observations, it is easy to agree with the overall picture of a schism, which took place in phases, was dependent on shifting demographics, and led to a marginalization of Jewish Jesus followers from emerging rabbinic Judaism and from nonJewish (orthodox) Christianity. In fact, this type of development has been suggested before, but from an archaeological perspective. Contrary to assertions made by Burns regarding a supposed lack of archaeological remains related to Christ-followers in Galilee (p. 53), the overall pattern of this historical reconstruction can be said to be corroborated by different types of approaches and source materials. (See A. Runesson, "Architecture, Conflict, and Identity Formation: Jews and Christians in Capernaum from the $1^{\text {st }}$ to the $6^{\text {th }}$ Century," in Religion, Ethnicity and Identity in Ancient Galilee: A Region in Transition. Edited by J. Zangenberg, H. W. Attridge, and D. Martin [Tübingen: Mohr Siebeck, 2007] 231-57. For studies of the archaeological remains, see, e.g., S. L. Matilla, "Capernaum, Village of Nahum, from Hellenistic to Byzantine Times," in Galilee in the Late Second Temple and Mishnaic Periods. Vol. 2: The Archaeological Record from Cities, Towns, and Villages. Edited by D. A. Fiensy and J. R. Strange [Minneapolis: Fortress, 2015], 217-57; Y. Tepper and L. Di Segni, A Christian Prayer Hall of the Third Century CE at Kefar 'Othnay [Legio]: Excavations at the Megiddo Prison [Jerusalem: IAA, 2006].)

While the book is well written, there are some terminological issues threatening to obscure the message the author seeks to convey. Among these, Burns' choice of "Christian," "Jew," and "Jewish Christian" is unfortunate. Speaking of Jewish Christians is problematic, as these people self-identified, and were also identified by the rabbis (so Burns argues) as Jews. Further, using "Christian" during this early period communicates a sense that "Christianity" was, in all its diversity, something other than "Judaism", an assumption which is demonstrably incorrect, and one which Burns, indeed, argues against.

Perhaps such terminological choices are also behind the somewhat unsatisfactory treatment in chapter three of Paul and the "Pauline Gospel." While it is of course legitimate to choose one's interpretive approach, the New Perspective has been thoroughly critiqued over the last fifteen years or so, most prominently by scholars now identified as working inside the Paul-Within-Judaism perspective. The situation is not helped by the fact that the latter perspective receives very little discussion. Burns ignores major studies that would have challenged his reconstruction (e.g., Kathy Ehrensperger, Paul at the Crossroads of Cultures: Theologizing in the Space-Between [London: Bloomsbury, 2013]; Paula Fredriksen, "Judaizing the Nations: The Ritual Demands of Paul's Gospel," New Testament Studies 56 [2010] 232-52.) Indeed, Burns' construction of two forms of Christianity, one related to Paul and the other to Matthew (and those with similar views), seems, despite the author's assurances to the contrary, to functionally 
reproduce the old and problematic paradigm dividing Christianity into Jewish Christianity and gentile Christianity, obscuring complexities such as blurred boundaries, shared practices, and interlinked identities.

Burns' claim that it is possible that Jewish believers in Jesus could be found in both synagogues and churches, leaving traces in the texts of other Jews and (non-Jewish) Christians, respectively, is important and addresses key issues in current debates. To develop this claim further, scholarship on ancient synagogues needs to be addressed more comprehensively, both in order to define the nature of these institutional settings and, more specifically, to validate some of the claims and their socio-institutional implications.

These limitations should not, however, take away from the overall impression of the book; it certainly has potential to contribute significantly to scholarly discussions as well as to Jewish-Christian dialogue. In both settings, Burns' study highlights how important it is for those seeking a fuller understanding of ancient Jewish life not to be bound by narratives told by those intent on establishing the normative status of some forms of Judaism while marginalizing others. Burns appropriately ends his book, commenting on the common ground for Jews and Christians that his study has revealed: "Should we hope to overcome the misgivings of those of our predecessors who wished to efface that common ground, we must strive to remember what the authors of the Christian schism so diligently labored to forget" (p. 254). 